\title{
Intellectual Property Rights and Monopoly in the Perspective of Islamic Jurisprudence
}

\author{
Meirison, ${ }^{1}$ Zerly Nazar ${ }^{2}$ \\ ${ }^{1}$ Universitas Islam Negeri Imam Bonjol Padang - Indonesia, ${ }^{2}$ Departemen of \\ Education Sidney - Australia \\ 1meirison@uinib.ac.id,2Zerly.Nazar@det.nsw.edu.au
}

\begin{abstract}
This paper aims to reveal figh's review of Intellectual Property Rights (IPR) and their relationship with monopolies that can harm humankind. There are two opinions in contemporary fiqh regarding IPR; first, Ahmad al-Hujjīal-Kurdī, which states that IPR as a part of worship, should not be hidden and should not be monopolized and exploited by anyone. Second, Muștafā Zarqā, Muhammad Fathī al-Duraynī, Muhammad Sa'î̀ Ramadān al-Būtī who agree with the protection of IPR. Through literature study and descriptive analysis approach, this paper concludes that if intellectual property rights cause harm to society and the state, especially in the exploitation of material rights, then it has created a monopoly that is detrimental and prohibited. Every country has different policies to protect IPR when it does not harm the community and the state.
\end{abstract}

Keywords: IPR; Islamic jurisprudence; intellectual wealth; monopoly

Tulisan ini bertujuan untuk mengungkap tinjauan figh tentang Hak Kekayaan Intelektual (HKI) dan hubungannya dengan monopoli yang dapat merugikan umatmanusia. Ada dua pendapat dalam fiqh kontemporer tentang HKI, pertama, Ahmad al-Hujjī al-Kurdī yang menyatakan bahwa HKI sebagai bagian dari ibadah, tidak boleh disembunyikan, dan tidak boleh dimonopoli dan dieksploitasi oleh siapapun. Kedua, Muștafā Zarqā, Muhammad Fathī al-Duraynī, Muhammad Sa'îd Ramadān al-Būțī yang setuju dengan perlindungan HKKI. Melalui studi pustaka dan pendekatan analisis deskriptif tulisan ini menyimpulkan bahwa jika HAKI menimbulkan kerugian bagi masyarakat dan negara, terutama dalam eksploitasi hak-hak material, maka telah menimbulkan monopoli yang merugikan dan terlarang. Setiap negara memiliki kebijakan yang berbeda, sehingga perlindungan terhadap HKI diterapkan ketika tidak merugikan masyarakat dan negara.

Kata Kunci: $\quad$ HKI; fiqh Islam; kekayaan intelektual; monopoli 


\section{Introduction}

Wealth is divided into two moral and material wealth. ${ }^{1}$ Moral wealth is attributed to the owner of scientific works, inventions, and creations in the form of a good name, fame, and contribution in the service of science. Material wealth is a reward for the services it provides as compensation for the benefits it has given to individuals, communities, countries, and even the international world. Intellectual property is a right that comes from human intellectual activities that produce moral and material benefits. Intellectual Property Rights (IPR) is a right arising from thoughts that have a product or process that is useful for the use of humans. ${ }^{2}$ The work becomes an object of protection. These works are divided into two, namely copyright and industrial property rights. ${ }^{3}$

Copyright and industrial property are two problems that have been raised in developed countries to protect their assets. This problem has existed for a long time in the Islamic world. ${ }^{4}$ However, because Islamic jurisprudence does not contradict it, this issue is not their primary concern. This situation was exacerbated by scientific stagnation in the Islamic world. Until the 18th century, Muslims had experienced total stagnation because the scientific atmosphere was no longer conducive to being filled with political, economic, and security pressures, both internally and externally. 5

This stagnation has resulted in the inability of Muslims to face Western civilization with the various kinds of discoveries they have made. More than that, they also created legal instruments to support their findings. Since the middle of the 18th century AD Agreement after agreement on a national and international scale, their discoveries were finally protected by law gradually to ensure the growth and safety of their scientists. Meanwhile, in Muslim countries, scientific life has long stalled. Many of the talented scientists migrate to

\footnotetext{
${ }^{1}$ Shihāb al-Dīn al-Qarafī, Anwār al-Burūq fì Anwa' al-Furūq (Kairo: Dār alHadìth, 2018), vols III; 115.

2 'Abd al-Karīm Șālih ‘Abd Al-Karīm, 'Al-Ițār al-Qānūnī Li Tadābir al-Himāyah al-Tiknūlūjiyah Li al-Musannafāt al-Raqmiyyah Dirāsah Tahlīliyah Muqāranah', Journal of Legal and Political Studies 3, no. 1 (1 April 2015): 168-201, https://doi.org/10.17656/jlps.10062.

${ }^{3}$ Javaid Iqbal Khan and Ahmad Lone Naveed, 'Intellectual Property Rights in Islam: A Perspective', International Journal of Research in Social Science 3, no. 1 (February 2013), http://www.ijmra.us153.

${ }^{4}$ Ahmad Juwaynī, Bayn al-Iḥtikār wa al-Ibtikār wa al-Irhāb al-Iqtiṣād (Mesir: Mațba'ah Shabāb, 2017).

${ }^{5}$ Umar Amin Husin, Kultur Islam, Sedjarah Perkembangan Kebudajaan Islam dan Pengaruhnja dalam Dunia Internasional (Jakarta: Bulan Bintang, 1964), 112.
} 
developed countries and create there. Their work is beneficial to industries in several countries, such as Japan, Europe, and the United States. For example, by Muslim scientists in Japan, the development of Nanotechnology made many discoveries in Europe and worked in data and digital technology. 6

Among the literature that reveals IPR and monopoly is the book written by Usāmah Muhammad' Uthmān Khalīl. He discussed the IPR that the Egyptian government had ratified, and it turned out to be causing harm to people's lives. That way, IPR must be tailored to the needs of society, with a focus on fairness and benefit. Also, Mulham bin Muhammad Mulham in his writing, explained that protection of IPR could spur competition in work. Therefore, IPR must be protected by national and international laws. However, it must be adjusted to the benefit of multilateral without exploitation which leads to monopoly. Meanwhile, this paper focuses on the review of maquassid al-sharī'ah and Islamic jurisprudence on monopoly and IPR as considerations for realizing benefit.

This paper discusses intellectual property related to monopoly due to absolute excessive use of copyright and intellectual property. The primary reference is the book entitled Bayn al-Iḥktikār wa al-Ibtikār by Juwaynī. Meanwhile, secondary sources are a book entitled Dusta Industri Pangan: Penelusuran Jejak Monsanto Penulis by Isabelle Delforge and Hungry for Trade: How the Poor Pay for Free Trade by John Madeley, and other works by the theme of this paper.

Through literature study, the author will explain the meaning of intellectual property in Islamic jurisprudence. This paper is qualitative with a comparative analysis method of the opinions of contemporary legal experts. The discussion also includes the copyright of his work and regarding the media. The protection provisions of all innovators' rights and intellectual property are also part of the contents of this paper.7

\section{IPR in Islam}

The protection of copyright and industrial property rights is intended to benefit the rights owners financially and morally. Protection of rights, if referring to the formulation of ușul al-fiqh, can be studied through the theory of

\footnotetext{
${ }^{6}$ Juwaynī, Bayn al-Ihtikār wa al-Ibtikār wa al-Irhāb al-Iqtis̄ād, 112.

7 Usāmah Muhammad 'Uthmān Khalīl, 'Al-Milkiyah al-Fikriyah fī Fiqh alIslāmī', n.d., 98, https://www.cia.gov/library/abbottabad-compound/E5/E58E

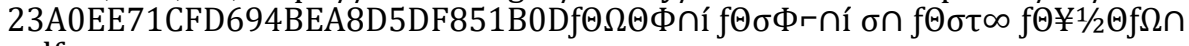
.pdf.
} 
mașlahah mursalah. ${ }^{8}$ This elaboration is essential so that the existence of protection for the work produced becomes clearer. The protection of this work for the Muslim community refers to international agreements by sticking to Islamic jurisprudence. More than that, the suggestion is that there should be some joint institution in safeguarding IPR and establishing a special court. Currently, support is also needed to develop scientific and industrial research so that they can compete globally.

\section{Rights and Freedoms in the Concept of Maqāșid al-Sharī'ah}

Several principles of rights in the context of maqāsid al-sharīah can be explained as follows: ${ }^{9}$

1. Islam is a religion that maintains the benefit of the world and the hereafter

Qur'an Surah 28: 77 explains that Islam perfectly regulates every line of life. This rule applies to every individual, community, and national relationship, including economic, social, and political. ${ }^{10}$ Every human being has the right to determine the type of work he likes according to his interests and talents based on the halalness of the process and the results. A person's independence is an achievement that is appreciated by religion.

2. Islam guarantees property rights

The right to ownership of an object, regardless of its type, is protected by Islam. This refuge is known as hifz al-māl, which is an essential part of the maqāșid al-sharī'ah building. Ownership is intangible objects and intangible things, such as ideas and intellectual works; this is in sync with the protection of reason (hifz al-'aql) which is also part of maqūṣid al-sharī'ah.

3. Islam protects freedom of opinion

${ }^{8}$ Dimas Fahmi Fikri and Afif Noor, 'Reformasi Hukum Wakaf di Indonesia Studi Terhadap Wakaf Hak Atas Kekayaan Intelektual', Al-Ahkam 22, no. 1 (11 April 2012): 18, https://doi.org/10.21580/AHKAM.2012.22.1.3.

${ }^{9}$ Syufa'at Syufa'at, 'Implementasi Maqāșid al-Sharī'ah dalam Hukum Ekonomi Islam', Al-Ahkam 23, no. 2 (21 October 2013): 148, https://doi.org/10.21580/ ahkam.2013.23.2.20; Maskur Rosyid, Implementasi Konsep Maslahat Al-Tūfĩ dalam Fatwa MUI (2005-2010), 1st ed. (Magelang: Ngudi Ilmu, 2013), 42.

${ }^{10}$ Reza Fahmi, 'Pengaruh Pembelajaran Kewirausahaan Terhadap Motivasi Berwirausaha', Share: Jurnal Ekonomi dan Keuangan Islam 1, no. 2 (31 December 2012): 99-117, https://doi.org/10.22373/share.v1i2.720. 
As principle number two above, protection of freedom of opinion is the main concern of Islam. Freedom of expression can take the form of written and scientific works. Works in the field of science are disseminated, both in written and oral form. It can be in the form of books, journals, and other scientific publications in written form. Meanwhile, the oral form can be in the form of seminars and conferences. This is in line with efforts to protect IPR.

The jurists did not discuss case by case but presented it in general terms. They agree that theft of any kind and any object, including ideas and scientific works, is a criminal act and is certainly not justified; the right to scientific work needs to be protected To protect against this theft.

Protection of scientific property rights, textually not found in the source of Islamic law. At the same time, this protection was not rejected by the texts. In this case, the maslahah mursalah ${ }^{11}$ theory applies. It is also following the main principles of fiqh, namely as a form of eliminating interdiction (دفع المفاسد) and attracting benefit (جلب المصالح)

Refusing losses and protecting the benefit of those entitled to intellectual property are things that the community wants. The innovators and authors who have produced published work have done it seriously and sacrificed time, energy, thoughts, and possessions. They are entitled to obtain material benefits or at least moral benefits from their work. Their heirs can also receive this right. Thus, plagiarizing work and reprinting a work without permission is a form of theft. ${ }^{12}$ Therefore, there must be compensation from the party who acted in material and moral forms.

The majority of legal experts recognize the preservation of IPR as a form of individual protection. Intellectual property can be categorized as part of the property ${ }^{13}$ that is entitled to a guarantee of protection. ${ }^{14}$ Looking for treasure aims to take advantage of these assets. Eliminating the benefits of an item has an

11 Maskur Rosyid and Anwar Hafidzi, 'Paradigma dan Alienasi Konsep Maslahat Al-Tufi Sebagai Legalitas Sumber Syariah', Al-Banjari : Jurnal Ilmiah Ilmu-Ilmu Keislaman 19, no. 2 (15 December 2020): 170, https://doi.org/10.18592/al-banjari.v19i2.3823.

12 Khalīl, 'Al-Milkiyah al-Fikriyah fỉ Fiqh al-Islāmī', 26.

${ }^{13}$ Khalìl, 26.

14 'Izz 'Abd al-'Azīn bin 'Abd Al-Salām, Bidāyah al-Sūl fì Tafọīl al-Rasūl (Lebanon: Dār al-Firk al-Mu'āșir, 1999), 167. 
impact on the obligation to replace it. This is intellectual property and the products it produces, which aim to achieve and spread its benefits. ${ }^{15}$ To deny this form of protection is tantamount to destroying the maqăsid al-shari'ah building, which impacts the destruction of religion.

\section{Islamic Initial Principles of Protection of IPR}

Attention to works in Islam can refer to the statement of Ibn Khaldūn. Experts' focus was focused on him, he said, on compiling scientific books and making corrections to the history attributed to the author. Attributing this is more important than editing and correcting writing errors. Therefore, every word and opinion must be attributed to the person who said it. Including the fatwa to the mufti, the istinbāt method of law to the mujtahid, and his madhhab. ${ }^{16}$

Muslims have long promoted scientific honesty. For example, in this case, in the writing of books, especially books related to hadith, who was very strict in selecting narrations. Reproducing the work of a scholar by writers will benefit them and perpetuate his work. The author does not expect money when the books are finished. More than that, there is a kind of appreciation given by the Abbasid dynasty government for someone who produces works. The concept of integrity was at the centre of any work done initially, as seen from the definition above. The reliance of a word on its source is a point of pressure. It's just that no standard rules are governing the procedures and sanctions given to violators. The format for protecting scientific works in the history of Islamic scholarship is presented in a simple form. It is only a kind of moral responsibility, and it does not come down to specific rules regarding this form of protection.

Protection of IPR then emerged in the Western world. It appeared as a result of the invention of the printing press and publishers that were scattered throughout Europe. The progress of the industry has provoked further scientific works to be recorded and published. This development has caught the attention

${ }^{15}$ Nūr 'Îsā al-Hindī, 'Intiqāl Huqūq al-Milkiyah al-Fikriyah Ilā al-Warathah fî Daw' al-Ma'āhadāt al-Dawliyah', Majallah Jāmi'ah ll-Shārifah li al-'Ulūm alShar'iyah wa Al-Qānūniyah 10, no. 1 (June 2013): 279-302, https://doi.org/ 10.12816/0007426.

${ }^{16}$ Ibn Khaldūn, Tārīkh Ibn Khaldūn al-Musammā Kitāb al-'Ibar wa Dīwān alMubtada' wa al-Khabar fí Ayyām al-'Arab wa al-'Ajam wa al-Barbar wa Man 'Āșarahum Min Dhawī al-Sulțān al-Akbar (Beirut: Dār al-Kutub al-'Ilmiyyah, 1992), 562. 
of legal experts because it has given rise to new symptoms related to legal and financial aspects that require new legal products to benefit innovators and compilers of books. ${ }^{17}$

This problem has become an international problem in regulating the rights of book authors and innovators. They then carried out a series of activities as follows. ${ }^{18}$ In 1858, the Brussels Congress established a legal framework for international recognition of IPR in works of art and literature. Second, the Bern Convention was held on September 9, 1886, in Paris, which had previously been formed by the arts and literary associations in 1876. Representatives of the countries present signed the first international agreement to protect all literary and artistic works. All Western countries were present, except for North Africa, which was still under the banner of the Ottoman Turks that Italy and France colonized.19 Several countries have also enacted regulations related to the protection of IPR. Even in England, this protection law has existed since 1710.

Meanwhile, the basic law related to protecting these rights was issued on December 16, 1911. The law includes protections for scientific works in books, music and painting, photography, sculpture, engineering, and carving. ${ }^{20}$ Sudan issued the first law on the protection of IPR in 1974. The law was renamed copyright protection law. In 1996 it was amended and replaced by the author protection law and the rights associated with it.21

Meanwhile, Indonesia declared its exit from the Bern Convention in 1958. This was announced directly by Prime Minister Djuanda so that Indonesian intellectuals could take advantage of scientific works without paying

\footnotetext{
${ }^{17}$ Al-Hindī, 'Intiqāl Huqūq al-Milkiyah al-Fikriyah ilā al-Warathah fī Ḍaw' alMa'āhadāt al-Dawliyah'.

${ }^{18}$ Nāșir bin Muhammad Al-Ghamidī, 'Himāyah al-Milkiyah al-Fikriyah fī alFiqh al-Issāmī wa al-Āthār al-Iqtis̄ādiyah al-Mutarattibah 'alayhā', n.d., 1438, https://almoslim.net/node/275713.

${ }_{19}$ Meirison Alizar and Qasim Muhammadi, 'Islamic Sharia and Non-Muslim Citizens in Kanunname During Sultan Abdul Hamid II of the Ottoman Empire', Walisongo: Jurnal Penelitian Sosial Keagamaan 27, no. 1 (30 July 2019): 37-68, https://doi.org/10.21580/ws.27.1.3543.

${ }^{20}$ Khalīl, 'Al-Milkiyah al-Fikriyah fỉ Fiqh al-Islāmī', 166.

${ }^{21}$ Muhammad Amanullah, 'Author's Copyright: An Islamic Perspective', The Journal of World Intellectual Property 9, no. 3 (1 May 2006): 301-15, https://doi. org/10.1111/j.1422-2213.2006.00279.x.
} 
royalties, which was deemed to have led to monopoly. ${ }^{22}$ Indonesia rejoined the New Order Era. Agreements and agreements signed by developed countries such as the GATT (General Agreement on Tariffs and Trade) in 1994 related to IPR. $^{23}$ Two things become the agreement, namely first, industrial property. Industrial property rights are divided into four types, namely, patent rights, trademark rights, industrial product rights, and trade secrets. Second, literature and artistic property (works of art) or copyrights. Ownership rights of literary and scientific works and literature include ownership of narrative history, poetry, writings, and scientific works, and others. ${ }^{24}$ However, the review of intellectual property ownership tends to be more towards individuals and groups who produce these works without considering the public benefit.

\section{Author Rights and Regulations}

The debate over the rights of authors and authors of books and other creations has long been debated. Meanwhile, related to scientific ideas and copyright, it should be disseminated after a book or other scientific work is published. This is both a symbol of the author's and inventor's progress with the scientific work. Author rights are temporary rights that are different from ownership rights to objects. Therefore IPR cannot be invested and monopolized by a person or companies. ${ }^{25}$ Adherents of this opinion state that an investor does not intend to keep the theory he invented or wrote a secret, but he intends to disseminate it. If the rights of authors and inventors are temporary rights, then work is not the same as ownership of an object. Contemporary scholars such as Fathī al-Duraynī, and others claim that the rights of authors and inventors are the same as ownership of things. He can exploit the work found

\footnotetext{
${ }^{22}$ S. Gautama, 'Indonesia dan Konvensi-Konvensi Tentang Hak Cipta', Jurnal Hukum \& Pembangunan 5, no. 3 (29 June 1975): 186, https://doi.org/10.21143 /jhp.vol5.no3.597.

${ }^{23}$ Nikita Cinthya Mangulu, 'Hak Pemegang Paten Memberikan Lisensi Menurut Undang-Undang Nomor 13 Tahun 2016 tentang Paten', Lex Privatum 6, no. 8 (4 February 2018): 11, https://ejournal.unsrat.ac.id/index.php/lexp rivatum/article/view/22875.

${ }^{24}$ Al-Ghamidī, 'Himāyah al-Milkiyah al-Fikriyah fī al-Fiqh al-Islāmī wa alĀthār al-Iqtișādiyah al-Mutarattibah 'alayhā', 98.

${ }^{25}$ Mulhim bin Hammad Mulhim, 'Al-Milkiyah al-Fikriyah bayn al-Ihtikār wa al-Ibtikār wa Qawā̄nīn al-Munāsifah', n.d., https://www.aleqt.com/2017/09/13 /article_1251176.html.
} 
and the books he has compiled in the same manner as the treatment of concrete objects. ${ }^{26}$

The French Court of Appeal did not consider the rights of authors and owners of scientific works the same as common ownership. The word property used for scientific work is a mistake that exists in civil law, both in commercial terms and in legal language. IPR are only in the form of granting limited privileges for the owner to exploit for a limited time. ${ }^{27}$ There are also difficulties in using IPR, namely moral rights, to disseminate scientific works. Moral rights continue to be attached to the writer or innovator, even though material rights are no longer obtained.

IPR in the form of moral rights cannot be traded, gifted, or mortgaged because they are different from material rights. Meanwhile, material rights can be used, pawned, or stopped from publication. Therefore, IPR include moral and material rights. ${ }^{28}$ Moral rights are closer to authors, innovators, and inventors. This is a personal privilege that has only belonged to him and his heir's family for the past 50 years. ${ }^{29}$ The division of IPR is divided into individual rights (moral) and material rights. Each right has implications after it has been assigned to a person.

The implications of the rights that will apply to authors, innovators, and inventors are, first, to fulfil the rights of intellectual property owners (writers, inventors, innovators, etc.) with all legal and fair media and to protect the public good. Second, maintaining rights by the provisions of Islamic law, with full awareness of responsibility to God, civil and criminal, and disseminating useful discoveries to society. This will be realized if the religious awareness is in the inventor.

IPR of religion, civil society, and the public good must all be protected. The competent authorities must prosecute parties who violate these rights following applicable policies. Owners of intellectual property have limited and not absolute rights. The goal is that people can enjoy and take advantage of his

\footnotetext{
${ }^{26}$ Fathī Al-Duraynī, Haq al-Ibtikār fī al-Fiqh al-Islāmī al-Muqāran (Beirut: Dār al-Furqān, 2019), 221.

${ }^{27}$ Khalīl, 'Al-Milkiyah al-Fikriyah fỉ Fiqh al-Islāmī', 116.

${ }^{28}$ Khalīl, 117.

${ }^{29}$ Husayn ibn Ma'lawī Al-Shahrānī, Huqūq al-Ikhtirā' wa al-Ta'līf fì al-Fiqh alIslāmì (Riyad: Dār Ṭaybah li al-Nashr wa-al-Tawzì', 2004), 19.
} 
work. This is as if writers and inventors of scientific work can exploit the results of their labour. A rule says;

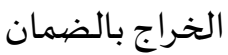

"income is compensation against the risk of bearing guarantees."

This guarantee is given by the authors, innovators, researchers, and inventors for all their findings and statements. Including bearing for all errors, malpractices, and wrong analysis of a theory. For the risks and guarantees he gives, he gets a reward in the form of al-kharäj (income) from his work.

\section{International Protection of IPR}

Muslim countries have attempted to enter into agreements in education, culture, and science in 1994.31 This is done to anticipate the negative impact of the application of monopolistic international IPR. For example, they take virus samples from developing countries, including Muslim countries, without any payment, then process it into a vaccine with a patent right and sold it at a high price. $^{32}$ They named it the Islamic Ummah Agreement Project. Article II states that Muslim countries recognize the need and benefit of protecting the rights of authors and authors of books. Therefore, an agreement is needed to support the production and publication of national and international scientific works. This agreement was made for the role of Muslims in building civilization in the Islamic world. ${ }^{33}$ The agreement includes: ${ }^{34}$

1. Books and papers and related.

2. All kinds of proceedings, religious and non-religious lectures.

3. Scripts and films.

4. Musical works, whether they have lyrics or not.

5. Dance and film scenarios.

6. Audio and audiovisual works.

7. Drawing, photography, architect, sculpture, carving, and stitching.

8. Geography and designs and prototypes, blueprints, and so on.

${ }^{30}$ Al-Shahrānī, 29.

${ }^{31}$ Khalīl, 'Al-Milkiyah al-Fikriyah fī Fiqh al-Islāmī', 21-48.

${ }^{32}$ Juwaynī, Bayn al-Ihtikār wa al-Ibtikār wa al-Irhāb al-Iqtișād, 29.

${ }^{33}$ Al-Duraynī, Haq ai-Ibtikār fì al-Fiqh al-Islāmī al-Muqāran, 221.

${ }^{34}$ Ahmad Hasan, Al-Ibtikār fì al-Fiqh al-Islāmī (Kairo: Dār al-Nahḍah al'Arabiyah, 2016), 91. 
Article 4 of the protection of material rights for the owner of intellectual property granting the right to limit the use of his work or reproduce it. Moral rights will remain attached to the owner, and he has the right to make changes and modifications to his work. The right owner can transfer his material rights to his heirs, but he cannot move the moral rights of his work to others. The period of validity of material rights is set according to the benefit. ${ }^{35}$

The institution agreed to establish an international committee for IPR owners, which includes: ${ }^{36}$

1. Study of the problems in realizing this agreement in the field.

2. Building communication between member countries regarding the development of protection against IPR.

3. Provide recommendations to the general chairperson about what the committee needs to be realized in the activities of educational organizations in the scientific and cultural fields.

\section{Absolute Protection of IPR}

Absolute protection of IPR can lead to monopoly, which can cause harm to society. This is because the ownership of copyright and industrial property rights can be exploited by third parties such as corporations and cartels. This utilization resulted in losses for both parties, especially the consumers. ${ }^{37}$

Monopoly (ihtikār) is defined as buying goods at a low price, hoarding them, and selling them when the price goes up. In jurisprudence, storing and hoarding goods to wait for a price increase is haraam. This is as explained by the Prophet as follows:

$$
\text { عن معمر بن عبد الله رضي اللهُ عَنْهُ عن رَسُول الله. قال لا يحتكر إلا خاطئ }
$$

From Ma'mar bin 'Abdillāh r.a He said: The Messenger of Allah said: "It is not a person who hoards unless He is a sinner",38

$$
\text { من احتكر حكرة يريد أن يغالي بها على المسلمين فهو خاطئ }
$$

\footnotetext{
${ }^{35}$ Al-Duraynī, Haq al-Ibtikār fì al-Fiqh al-Islāmī al-Muqāran, 97.

${ }^{36}$ Juwaynī, Bayn al-Ihtikār wa al-Ibtikār wa al-Irhāb al-Iqtiṣād, 211.

${ }^{37}$ Abū Kurkhī Haysham Hanī, Tanzìm al-Munāfasah wa Màn' al-Ihtikār Dimn Ittifāqiyāt Munāzamah al-Tijārah (Amman: The University of Jordan, 2015), 221.

${ }^{38}$ Muslim bin Al-Hajjāj, Sahịh Muslim, I (Libanon: Dār al-Fikr, 1992), vols II; 343; Muhammad Mukhtāruddīn Al-Falimbānī, Bulūgh al-Amānī (Beirut: Dār alDutaybah, 1988), 22.
} 
Every Muslim who hoarding to raise the price is a $\sin ^{39}$

The two hadīths above clearly explain the definition of ihtikār. Abū Yūsuf and a group of scholars who agree with him say that ihtikār is harām (forbidden) in all things, including food, animals, currency, and clothing. ${ }^{40} \mathrm{He}$ said: كل ما يضر الناس حبسـ فهو احتكار "everything that harms human beings when it is withheld (hidden) then that is ihtikār" ${ }^{41}$

The prohibition of monopolizing an item is intended to prevent damage from being caused. At the same time to realize human welfare. The preservation of IPR and the prevention of monopolies are the protection of life and property. It is even related to maintaining religion and honour. This is where the writers and inventors manifest the critical point of Islamic assertiveness in preserving the freedom of opinion. Expressing an argument is a mandatory thing. IPR can be classified as tradable goods, and there can be a monopoly on the commodity. Although IPR are classified as services or employment, they are inseparable from monopolistic practices. As stated by Abū Yūsuf above that everything that does harm if he is detained then is a monopoly. ${ }^{42}$ The owner of intellectual property with the copyright will generate largely and multiplied income supported by companies and cartels between continents, eventually leading to a monopoly that harms humankind. Islam maintains between individual rights, community rights, and the rights of Allah. ${ }^{3}$

\section{Impact of Absolute IPR Protection}

Protection of copyright and patent rights has become a source of life for Transnational Corporations (TNCs). Giant corporations, in particular, have a lot

${ }^{39}$ Mūsā Shāhin Lāshin, Fatḥ al-Mun'im Sharḥ Șahịh Muslim (Kairo: Dār alShurūq, 2002), 357.

${ }^{40}$ G. R. Hawting, 'Taxation in Islam. Vol. III: Abū Yūsuf's Kitāb Al-Kharāj. Translated and Provided with an Introduction and Notes by A. Ben Shemesh. Pp. Viii, 155. London, Luzac \&amp; Co., 1969. £4.25.', Journal of the Royal Asiatic Society of Great Britain \& Ireland 103, no. 2 (15 April 1971): 190, https://doi.org/ 10.1017/S0035869X00129296.

${ }^{41}$ Dār Al-Iftā' al-Mișriyah, Hukm al-Ihtikār (Kairo: Dār al-Iftā', n.d.), 28.

${ }^{42}$ Abū Yūsuf Ya'qūb, Taxation in Íslam, ed. Shemesh. Aharon Ben, vol. 3 (London: E. J. Brill, 1969), 97.

${ }^{43}$ Meirison Meirison, 'Administration and Finance System of the Ottoman Empire', Jurnal Ilmiah al-Syir'ah 18, no. 2 (27 December 2020): 91, https://doi. org/10.30984/jis.v18i2.1113. 
of funds to research and develop patented products, including legal tools to cover them. Global trade rules on patents allow giant corporations to control rights or various products in any country ${ }^{44}$ At the expense of the people, this corporation took a colossal advantage. The industrial community developed patents to reward the inventors of the machine.

Today, 97 per cent of all patents in the world are held by corporations in Western countries. These corporations quickly spread their patents to developing countries. TNCs now maintain as many as $80 \%$ of patents on technology and products in developing countries. ${ }^{45}$

In the 1990s, TNCs began enforcing patents on plant species in Africa, Asia, and Latin America. They are convinced that a massive investment in breeding activities will be made only if the investment is protected. Among NGOs, there is a mutual agreement that patents do not apply to biological forms, such as plants, which have been developed for centuries by farmers. The West has done its best to blackmail developing countries. ${ }^{46}$

\section{IPR and Trade}

The Uruguay Round Agreement on Trade-Related Intellectual Property Rights (TRIPs) establishes comprehensive rules and standards for IPRs related to international trade. ${ }^{47}$ TRIPs came into effect in January 1995 and give rights to corporations to protect their "intellectual property" in member countries of the World Trade Organization (WTO). The agreement covers the interests of TNCs, is the most comprehensive international agreement on IPR, and adds to the conventions of the World Intellectual Property Organization. With various substantive obligations under WTO rules, they regulate an agreement on the patenting of plant seeds, which results in several types of problems, including in Indonesia. ${ }^{48}$

Coupled with the GATT agreement in IPR named Trade-Related Aspects of Intellectual Property Rights (TRIPS), the countries that signed this agreement

\footnotetext{
${ }^{44}$ John Madeley, Hungry for Trade: How the Poor Pay for Free Trade (London: Zed Books, 2000), 144.

${ }^{45}$ Madeley, 145.

${ }^{46}$ Madeley, 146.

${ }^{47}$ Madeley, 147.

48 Isabelle Delforge, Dusta Industri Pangan: Penelusuran Jejak Monsanto Penulis (Yogyakarta: Insist, 2003), 169-70.
} 
have been bound and are obliged to implement the points of the agreement in their respective countries. There is a hidden purpose of these agreements and regulations, namely to stem the technology transfer in developing countries. It continues to depend on developed countries in all respects. ${ }^{49}$ However, developing countries can also analyze the obligations and rules of the agreement adjusted to national interests by utilizing the existing facilities in the TRIPS agreement, such as Iran and Malaysia, so that the impact of copyright monopoly and industrial property rights can be reduced. 50

Controversy over the benefits of IPR always occurs between poor and rich countries, especially in agriculture, medicine, software, and other programs. Licensing of drugs, for example, makes poor countries worse off. This is very detrimental to local drug companies who are able to produce similar drugs at lower prices. Protection of IPR cannot continue to be applied if it causes harm, especially in logistics and medicine. Several countries, such as South Africa and Egypt, are threatened not to implement the TRIPS agreement because if the drug prices are implemented, the prices of drugs will increase threefold, causing many fiaschi. ${ }^{51}$

\section{Between Monopoly and Copyright}

IPR is a new problem with no specific argument in the Qur'an, hadith, ijma $\bar{a}^{\prime}$ (consensus of the mujtahids), opinions of șạābah, and mujtahids. Therefore, contemporary scholars differ on this issue. Ahmad al-Hujjì al-Kurdī, a contemporary scholar, denies the material rights of authors or owners of intellectual property. There are no financial consequences in the case caused by the copyright. 52

He based his opinion on the Qur'an Surah 2: 152. The verse was revealed against the Jewish religious leaders (Ruhban) who hid the truth and justified falsehood. This verse cannot be used as an argument that material rights which

\footnotetext{
${ }^{49}$ Madeley, Hungry for Trade: How the Poor Pay for Free Trade, 149.

50 'Uthmān Ibrāhīm 'Abd al-Mun'im Mahmūd, 'Ahkām Fiqhiyyah al-Mutțaliqāt bi al-Mihnah Șaydaliyyah wa Sina'ah al-Dawā': Dirāsah Fiqhiyah Tațbīqiyyah' (Mansoura Egypt, 2019), 122.

${ }^{51}$ Mahmūùd, 122.

${ }^{52}$ Aḥmad Ḥajjī Al-Kurdī, 'Hukm Islām fì Ḥuqūq al-Ta'līf wa al-Nashr wa alTarjamah', Hudāa al-Islām, 1981, 25-28.
} 
are a component of IPR, are prohibited. While referring to hadith, the Prophet saw. said:

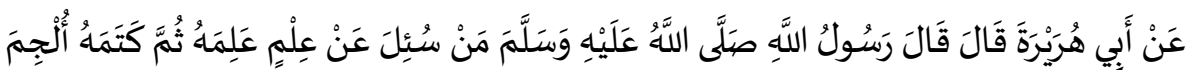

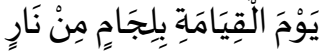

From Abū Hurayrah, he said: The Prophet said: whoever is asked about a knowledge that he knows, then he hides it, then he will be given a noose from hell on the Day of Judgment

In Islamic teachings, knowledge is helpful as a means of worship and a symbol of obedience to God. It cannot be traded or as part of a commercial craft. The implementation of worship activities is free of charge. Therefore, a teacher must do his teaching without any compensation. The welfare of teachers is obtained from the people and the government.

Meanwhile, the second opinion was stated by Mușțafā al-Zarqā,53 Muhammad Fathī Duraynī, al-Būțī, and Wahbah al-Zuhaylī that copyright and copyright must be fulfilled both in the form of moral and material rights. ${ }^{54}$ This second opinion made him aware of two things-first, the benefit, which is considered valuable and can be measured by money as compensation. There is an opinion which states that asking for payment for the use of IPR is the same as hiding knowledge. Meanwhile, not spreading knowledge is forbidden. However, the verse regarding concealment has to do with hiding the truth and exposing the iniquities committed by Jews. It has nothing to do with copyright which gives rise to material rights, and it is classified as a monopolistic practise when someone's knowledge is hidden. While humankind needs it, the new rights owner will issue them when they are rewarded with a very high fee. Practices like this, of course, have an impact on the death of many people.

The second basis is customs in the case of justification for copyright and IPR over labour, which can be exchanged for money or any reward. Of course, these efforts and benefits have been considered lawful by custom and do not differ from the texts. Majmā' al-Fiqh al-Islāmī states that if a person's work is accustomed to being valued in money, it is considered something with measurable value. Regarding taking wages, this is not prohibited by the

\footnotetext{
${ }^{53}$ Musțafā Aḥmad Al-Zarqā, al-Madkhal ilā Nazariyāt al-Iltizām al-'Āmmah fī al-Fiqh à̀-Islāmì̀ (Damaskus: Dār al-Qalam, 1999), 331.

${ }^{54}$ Al-Duraynī, Haq al-Ibtikār fí al-Fiqh al-Islāmī al-Muqāran, 136.
} 
shari'ah. ${ }^{55}$ As a result, the work's creator receives more material advantages than the publisher. Also, publishers have enjoyed profits for years, while owners of works are getting almost nothing. 56

The moral rights of the owners of intellectual property are regulated in Islamic jurisprudence. As mentioned at the beginning, attributing a word not to its owner, is a forbidden act. Every thought and opinion must be attributed to the thinker and the owner of the opinion. This is so that he gets a reward or bears the blame for his deeds. ${ }^{57} \mathrm{Al}$-Ghazzāli narrated Ahmad ibn Ḥanbal's attitude that he did not dare to quote or write someone's opinion until he obtained permission from the owner of the book and that opinion. 58 Whereas material rights, when referring to fiqh principles, everyone can receive compensation for their actions. 59

\section{Mașlahah Mursalah and IPR Material Rights}

None of the arguments against the sale and purchase of IPRs, and at the same time, there are no arguments to support these actions. If the benefit is obtained in this IPR transaction, it can be considered legal in Islamic jurisprudence. This is based on the concept of maslahah mursalah. The benefits that are maintained in IPR are the benefit of the authors and publishers as well as all parties. Fathu Duraini stated that IPRs can be traded and inherited within a specific time and are considered valuable objects. If there is a theft of IPR, the perpetrator can be prosecuted legally. Moreover, IPRs are valid for life and can be inherited for 60 years. After that, it becomes a public property that can be distributed without any consequences. ${ }^{60}$

Benefit can be realized if the results of someone's work are distributed not for commercial purposes. However, IPR owners can take advantage of their

${ }^{55}$ Hasan, Al-Ibtikār fì al-Fiqh al-Islāmī, 27.

${ }^{56}$ Hasan, 123.

57 Muhammad Sa'īd Ramaḍān Al-Būțī, Qaḍāyā Fiqhiyah Mu'āṣirah (Dār alFārābī, 2001), 83.

${ }^{58}$ Manșūr bin Yūnus bin Idrīs Al-Bahūtī, Kashf al-Qinā' 'an Matn al-Iqnā' (Beirut: Dārr al-Kutub al-'Ilmiyyah, 2009), vols IV; 64.

59 Meirison Meirison, Desmadi Saharuddin, and Rosdialena Rosdialena, 'Takhrij Fikih dan Permasalahan Kontemporer', Al-Istinbath: Jurnal Hukum Islam 5, no. 1 (9 May 2020): 51, https://doi.org/10.29240/jhi.v5i1.1235.

${ }^{60}$ Al-Duraynī, Haq al-Ibtikār fí al-Fiqh al-Islāmì al-Muqāran, 253. 
material rights if used in a commercial form. ${ }^{61}$ It can be said that when IPRs cause harm to many people, they are prohibited. As in the case of viral engineering, which is obtained free of charge from poor countries is then sold at a very high price. Ownership of IPR is not actual ownership like ownership of movable and immovable assets. A person is given exclusive rights to concrete objects that do not harm others if they are obtained by legal means. Meanwhile, the copyright of a book belongs to the author. This is because written works result from hard work of thought entitled to the same exclusive rights as a monopoly.

\section{Conclusion}

Based on the above description, the conclusion of this paper is as follows. The result of thought is not something concrete, so it cannot be equated with the property. In Islamic jurisprudence, HKI can be recognized absolutely in the form of moral rights. While in the form of material rights, there are differences of opinion. Material rights can be enforced in the circumstances; first, when another party commercializes material rights, the first party has agreed. Second, it is applied temporarily and attached to the work owner and can be passed on to his descendants for 60 years. After that, it became a public right. Material rights to IPR can be terminated if it has caused harm to the general public and the country. Referring to the principle of monopoly, which causes damage, then this becomes prohibited.

The Giver of compensation for researchers, inventors, and experts' efforts is charged to the government and society. Such awards can impact the advancement of science and the rise of Muslim intellectuals, which have been very difficult to realize.[a]

\section{BIBLIOGRAPHY}

Alizar, Meirison, and Qasim Muhammadi. 'Islamic Sharia and Non-Muslim Citizens in Kanunname During Sultan Abdul Hamid II of the Ottoman Empire'. Walisongo: Jurnal Penelitian Sosial Keagamaan 27, no. 1 (30 July 2019): 37-68. https://doi.org/10.21580/ws.27.1.3543.

${ }^{61}$ Ḥasan, Al-Ibtikār fĩ al-Fiqh al-Islāmī, 191. 
Amanullah, Muhammad. 'Author's Copyright: An Islamic Perspective'. The Journal of World Intellectual Property 9, no. 3 (1 May 2006): 301-15. https://doi.org/10.1111/j.1422-2213.2006.00279.x.

Al-Bahūtī, Manșūr bin Yūnus bin Idrīs. Kashf al-Qinā' 'an Matn al-Iqnā'. Beirut: Dār al-Kutub al-'Ilmiyyah, 2009.

Al-Būṭī, Muhạmmad Sa'îd Ramaḍān. Qaḍāyā Fiqhiyah Mu'ạșirah. Dār alFārābī, 2001.

Dār Al-Iftā' al-Mișriyah. Hukm al-Iḥtikār. Kairo: Dār al-Iftā', n.d.

Delforge, Isabelle. Dusta Industri Pangan: Penelusuran Jejak Monsanto Penulis. Yogyakarta: Insist, 2003.

Al-Duraynī, Fathī. Haq al-Ibtikār fì al-Fiqh al-Islāmī al-Muqāran. Beirut: Dār al-Furqān, 2019.

Al-Falimbānī, Muḥammad Mukhtāruddīn. Bulūgh al-Amānī. Beirut: Dār al-Dutaybah, 1988.

Fahmi Fikri, Dimas, and Afif Noor. 'Reformasi Hukum Wakaf di Indonesia Studi Terhadap Wakaf Hak Atas Kekayaan Intelektual'. Al-Ahkam 22, no. 1 (11 April 2012): 43-60. https://doi.org/10.21580/Ahkam. 2012.22.1.3.

Fahmi, Reza. 'Pengaruh Pembelajaran Kewirausahaan terhadap Motivasi Berwirausaha'. Share: Jurnal Ekonomi dan Keuangan Islam 1, no. 2 (31 December 2012): 99-117. https://doi.org/10.22373/share. v1i2.720.

Gautama, S. 'Indonesia dan Konvensi-Konvensi tentang Hak Cipta'. Jurnal Hukum \& Pembangunan 5, no. 3 (29 June 1975). https://doi.org/ 10.21143/jhp.vol5.no3.597.

Al-Ghamidī, Nāșir bin Muhammad. 'Himāyah al-Milkiyah al-Fikriyah fī alFiqh al-Islāmī wa al-Āthār al-Iqtișādiyah al-Mutarattibah 'alayhā', n.d. https://almoslim.net/node/275713.

Hanī, Abū Kurkhī Haysham. Tanẓim al-Munāfasah wa Man' al-Ihtikār Dimn Ittifāqiyāt Munāzamah al-Tijärah. Amman: The University of Jordan, 2015.

Ḥasan, Ahmad. Al-Ibtikār fĩ al-Fiqh al-Islāmī. Kairo: Dār al-Nahḍah al'Arabiyah, 2016.

Hawting, G. R. 'Taxation in Islam. Vol. III: Abū Yūsuf's Kitāb Al-Kharāj. Translated and Provided with an Introduction and Notes by A. Ben Shemesh. Pp. Viii, 155. London, Luzac \&amp; Co., 1969. £4.25.' Journal of the Royal Asiatic Society of Great Britain \& Ireland 103, no. 2 (15 April 1971): 190-190. https://doi.org/10.1017/ S0035869X00129296. 
Al-Hindī, Nūr 'Īsā. 'Intiqāl Ḥuqūq al-Milkiyah al-Fikriyah ilā al-Warathah fì Daw' al-Ma'āhadāt al-Dawliyah'. Majallah Jāmi'ah al-Shārifah li al'Ulūm al-Shar'iyah wa al-Qānūniyah 10, no. 1 (June 2013): 279-302. https://doi.org/10.12816/0007426.

Husin, Umar Amin. Kultur Islam, Sedjarah Perkembangan Kebudajaan Islam dan Pengaruhnja dalam Dunia Internasional. Jakarta: Bulan Bintang, 1964.

Juwaynī, Ahmad. Bayn al-Ihtikār wa al-Ibtikār wa al-Irhāb al-Iqtișād. Mesir: Mațba'ah Shabāb, 2017.

Al-Karīm, 'Abd al-Karīm Șāiḥ ‘Abd. 'Al-Ițār al-Qānūnī li Tadābir alHimāyah al-Tiknūlūjiyah li al-Mușannafāt al-Raqmiyyah Dirāsah Tahlīliyah Muqāranah'. Journal of Legal and Political Studies 3, no. 1 (1 April 2015): 168-201. https://doi.org/10.17656/jlps.10062.

Khaldūn, Ibn. Tārīkh Ibn Khaldūn al-Musammā Kitāb al-'Ibar wa Dīwān alMubtada' wa al-Khabar fi Ayyām al-'Arab wa al-'Ajam wa al-Barbar wa Man 'Āṣarahum Min Dhawī al-Sulțān al-Akbar. Beirut: Dār alKutub al-'Ilmiyyah, 1992.

Khalīl, Usāmah Muhammad 'Uthmān. 'Al-Milkiyah al-Fikriyah fĩ Fiqh alIslāmì', n.d. https://www.cia.gov/library/abbottabad-compound/

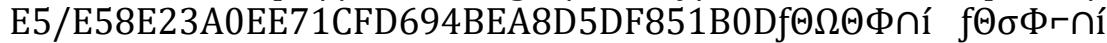
$\sigma \cap f \Theta \sigma \tau \infty f \Theta ¥ 1 / 2 \Theta f \Omega \cap$.pdf.

Khan, Javaid Iqbal, and Ahmad Lone Naveed. 'Intellectual Property Rights in Islam: A Perspective'. International Journal of Research in Social Science 3, no. 1 (February 2013). http://www.ijmra.us153.

Al-Kurdī, Ahmad Hajjīi ' 'Hukm Islām fỉ Ḥuqūq al-Ta'līf wa al-Nashr wa alTarjamah'. Hudā Al-Islām, 1981.

Lāshin, Mūsā Shāhin. Fath Al-Mun'im Sharh Sahịh Muslim. Kairo: Dār alShurūq, 2002.

Madeley, John. Hungry for Trade: How the Poor Pay for Free Trade. London: Zed Books, 2000.

Mahmūd, 'Uthmān Ibrāhīm 'Abd al-Mun'im. 'Aḥkām Fiqhiyyah alMutțaliqāt bi al-Mihnah Șaydaliyyah wa Sina'ah al-Dawā': Dirāsah Fiqhiyah Tațbīqiyyah'. Mansoura Egypt, 2019.

Mangulu, Nikita Cinthya. 'Hak Pemegang Paten Memberikan Lisensi Menurut Undang-Undang Nomor 13 Tahun 2016 tentang Paten'. Lex Privatum 6, no. 8 (4 February 2018). https://ejournal.unsrat.ac.id/ index.php/lexprivatum/article/view/22875.

Meirison, Meirison. 'Administration and Finance System of the Ottoman Empire'. Jurnal Ilmiah Al-Syir'ah 18, no. 2 (27 December 2020). 
https://doi.org/10.30984/jis.v18i2.1113.

Meirison, Meirison, Desmadi Saharuddin, and Rosdialena Rosdialena. 'Takhrij Fikih dan Permasalahan Kontemporer'. Al-Istinbath: Jurnal Hukum Islam 5, no. 1 (9 May 2020). https://doi.org/10.29240/jhi. v5i1.1235.

Mulḥim, Mulhim bin Ḥammad. 'Al-Milkiyah al-Fikriyah bayn al-Iḥtikār wa al-Ibtikār wa Qawānīn al-Munāsifah', n.d. https://www.aleqt.com/ 2017/09/13/article_1251176.html.

Muslim bin Al-Ḥajjāj. Șahịh Muslim. I. Libanon: Dār al-Fikr, 1992.

Al-Qarafì, Shihāb al-Dīn. Anwār al-Burūq fì Anwa' al-Furūq. Kairo: Dār alHadìth, 2018.

Rosyid, Maskur. Implementasi Konsep Maslahat Al-Ṭüfi dalam Fatwa MUI (2005-2010). 1st ed. Magelang: Ngudi Ilmu, 2013.

Rosyid, Maskur, and Anwar Hafidzi. 'Paradigma dan Alienasi Konsep Maslahat Al-Tufi Sebagai Legalitas Sumber Syariah'. Al-Banjari: Jurnal Ilmiah Ilmu-Ilmu Keislaman 19, no. 2 (15 December 2020). https://doi.org/10.18592/al-banjari.v19i2.3823.

Al-Salām, 'Izz 'Abd al-'Azīn bin 'Abd. Bidāyah al-Sūl fĩ Tafḍil al-Rasūl. Lebanon: Dār al-Firk al-Mu'āșir, 1999.

Al-Shahrānī, Ḥusayn ibn Ma'lawī. Huquūq al-Ikhtirā' wa al-Ta'līf fì al-Fiqh al-Islāmì. Riyad: Dār Țaybah li al-Nashr wa-al-Tawzī', 2004.

Syufa'at, Syufa'at. 'Implementasi Maqāṣid al-Sharī'ah dalam Hukum Ekonomi Islam'. Al-Ahkam 23, no. 2 (21 October 2013): 143. https://doi.org/10.21580/ahkam.2013.23.2.20.

Ya'qūb, Abū Yūsuf. Taxation in Islam. Edited by Shemesh. Aharon Ben. Vol. 3. London: E. J. Brill, 1969.

Al-Zarqā, Mușțafā Aḥmad. Al-Madkhal ilā Nazariyāt al-Iltizām al-'Āmmah fì al-Fiqh al-Islämī. Damaskus: Dār al-Qalam, 1999. 